\title{
A CO-RELATION STUDY TO ASSESS PARENTAL KNOWLEDGE AND ATTITUDE REGARDING THE IMPACT OF TELEVISION ON CHILDREN IN SELECTED AREA KANPUR, U.P
}

\author{
Pratibha Srivastava \\ M.Sc (C.H.N), Associate Professor, \\ Rama college of Nursing, Rama University \\ Mandhana, Kanpur, Uttar Pradesh, India.
}

Article DOI: https://doi.org/10.36713/epra4759

\begin{abstract}
Today's Children will be tomorrow's responsible citizen of the country.

Entertainment is an essential part of life, by this we feel tension free, relaxed, energetic and having a positive attitude towards life. Games plays an important role for the all round development of the children's personality especially outdoor games but Now a days children are adopting habits of playing indoor games and also entertaining themselves by using various electronic devices as we know one of them is television. There are various programmes such as various kids' channels, cartoon shows, video games etc. being watched by the children. Directly or indirectly these programs affect behaviour of the children in positive and negative ways. That's why it is needed that parents should have a look for types of programmes seen by children, how long a child is watching a program, how it is affecting child habits/behaviour etc. Later on, these negative impacts will create health issues/behaviour problems such as obesity, aggressive behaviour, lack of concentration etc.

Child who watch television for 10 hours or more per week are less skilled at reading and are less successful in school as compared to children who watch television for less than 10 hours per week. The American academy of paediatrics makes the following recommendations regarding television viewing should not exceed one to two hours of quality programming daily and children younger than two years old should not watch television. ${ }^{I}$

That is why researchers took this topic to highlight the attitude and knowledge of parents about the impact of television on their Children's behaviour.

A co-relational study conducted to assess parental knowledge and attitude regarding the impact of television on children in selected area at Kanpur (U.P). A descriptive cross-sectional survey approach was used, sample size was 100 parents selected by convenient sampling for this study. Self-structured knowledge questionnaire was used to assess the knowledge of parents, and attitude of parents was assessed by Likert scale. The study shows that among 100 parents $8 \%$ of them had poor knowledge, $36 \%$ average knowledge, $50 \%$ good knowledge, $6 \%$ very good knowledge about impact of television on children. The study shown the positive attitude $84 \%$, negative attitude $16 \%$ on impact of television on children. The correlation value shows that positive correlation between knowledge and attitude score of parents. There was no significant association between knowledge score with their demographic variables and significant association seen between attitude score with types of family, educational status of parents, income of parents and number of children. There was no significant association between attitude score with age of parents and religion.
\end{abstract}

KEYWORDS: Impact, Television, Attitude, Parental Knowledge, 


\section{INTRODUCTION}

$\mathrm{TV}$ is a good tool for children to relax, entertain or just spend time. Television helps in mental development of children as well as informs children about new things, increases their vocabulary, and watching good programs makes their behaviour good, children get knowledge of right-wrong, goodbad deeds. All this is possible only when parents provide the right guidance to the children, tell them what kind of programs are good for them, how long they should watch the programs, decide their time, turn off the TV while eating food, ensure they do not see programs that have a bad effect on them. . ${ }^{2}$

Television is the most powerful and influential media of communication worldwide. Due to its powerful influence, most advertisers advertise their product to attract school going children as they are the target audience in most cases. This is due to the fact that school-going children are innocent and readily agree to buy any particular product, which is being advertised on television. ${ }^{3}$

\section{OBJECTIVES}

- To assess the knowledge of parents on impact of television viewing on children in selected community area Kanpur.

- To assess the attitude of parents on impact of television viewing on children in selected community area, Kanpur.

- To find out co-relation between the level of knowledge and attitude of parents regarding the impact of television on children in selected area in community, Kanpur.

- To find out the association between the level of knowledge score with selected demographic variables.

- To find out the association between the level of attitude score with selected demographic variables.

\section{HYPOTHESIS}

- There is a significant association between knowledge score of parents with their selected demographic variables.

- There is a significant association between attitude score of parents with their selected demographic variables.

- There is a significant correlation between knowledge and attitude score of parents.

\section{Delimitation-}

The study was delimited to only urban area of Kalyanpur.

Data collection was delimited to 2 weeks.

\section{METHODOLOGY}

- Research Approach - Descriptive crosssectional survey approach.

- Research Design- Descriptive co-relational study design.

- Setting Of The Study - urban area of Kalyanpur , Kanpur.

- Population - All the parents of school going children in Kanpur.

- Accessible Population- All parents of school going children in a selected area of Kalyanpur.

- Sample- Parents of school going children between the age group of 6-12 years residing at selected area of Kalyanpur.

- Sample Size - 100 parents of school going children.

- Sampling Technique- Convenient Sampling techniques.

\section{Sampling Criteria}

- Inclusion criteria -

Parent who are having children between age groups of 6-12 yrs

Available at the time of data collection.

- Exclusion criteria -

Parents who are not willing to participate.

Parents of children who are suffering from MR (mental retardation).

Development of tools:

\section{Research tool consist of three sections Section- A}

Demographic data of the parents of school going children such as age of parents, type of family, educational status of parents, income of the family, religion, no. of children,

\section{Section-B}

Structured knowledge questionnaire to Section $-\mathrm{C}$ assess knowledge score of parents.

Likert scale to assess attitude score of parents. 


\section{RESULT}

Diagrammatic presentation of demographic variables found in this study:

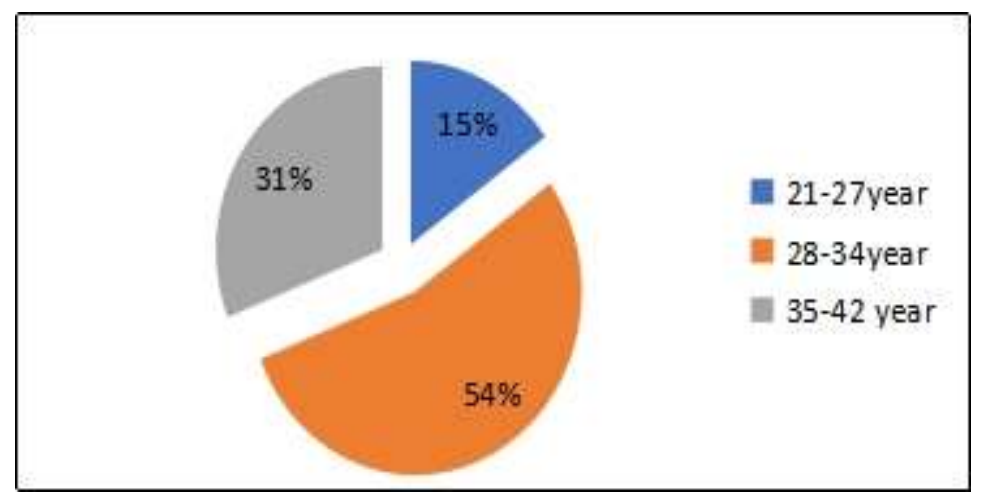

Fig.no.1 Pie Diagram Shows percentage by the distribution of age group.

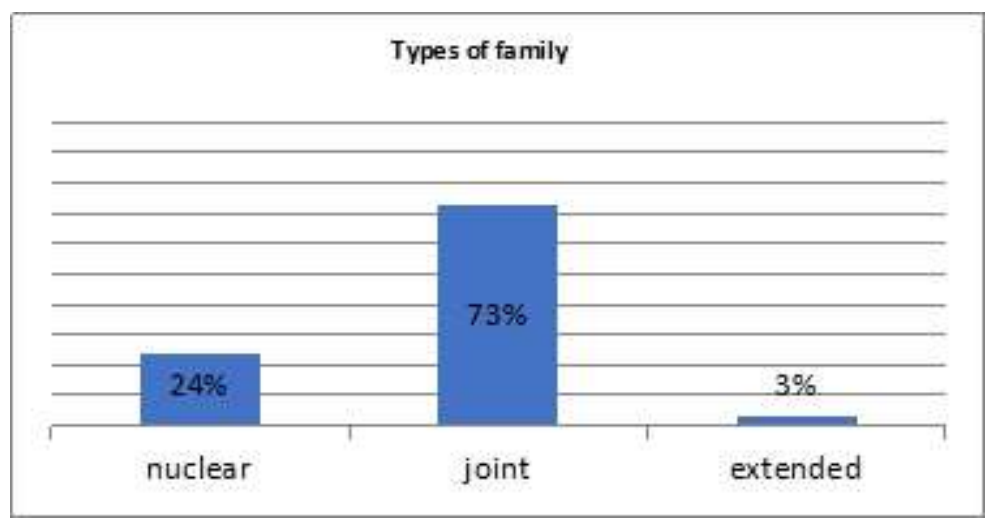

Fig.no.2: Column diagram shows the percentage by the distribution of type of family

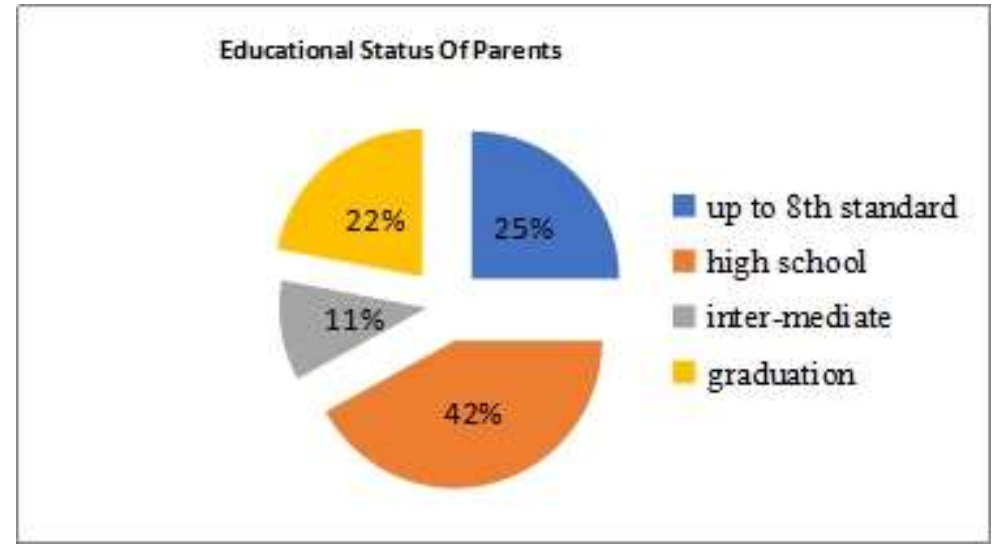

Fig.no.3 Pie diagram shows the percentage-wise distribution of educational status of parents 


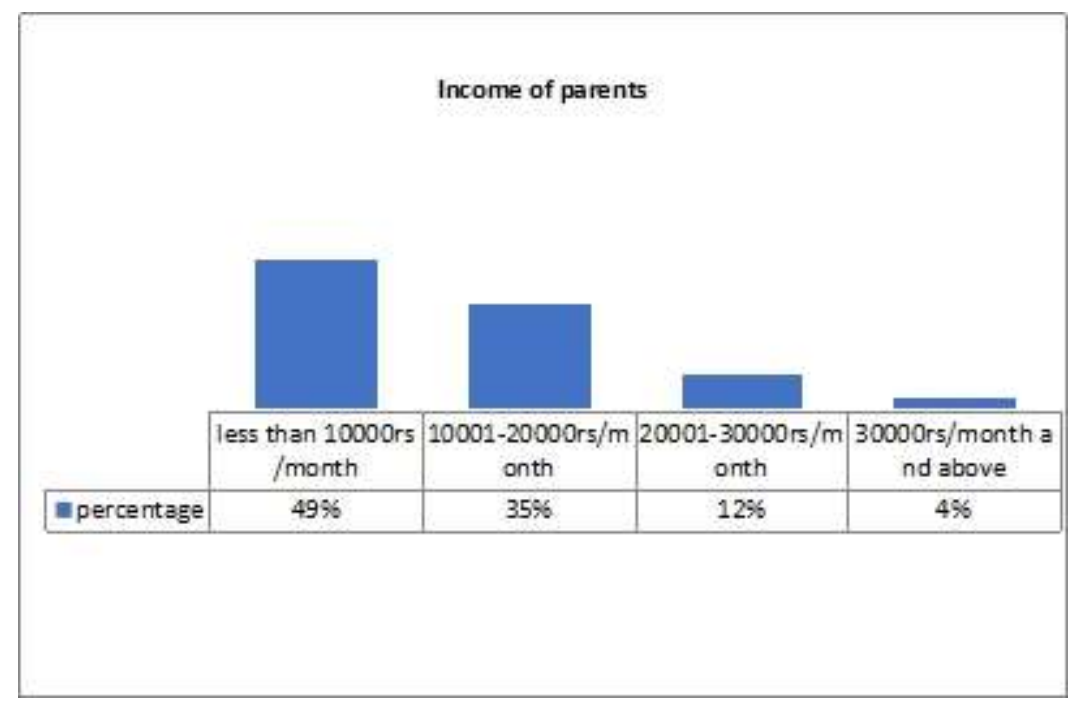

Fig. No.4: Cylindrical diagram shows the percentage-wise distribution of income of parents

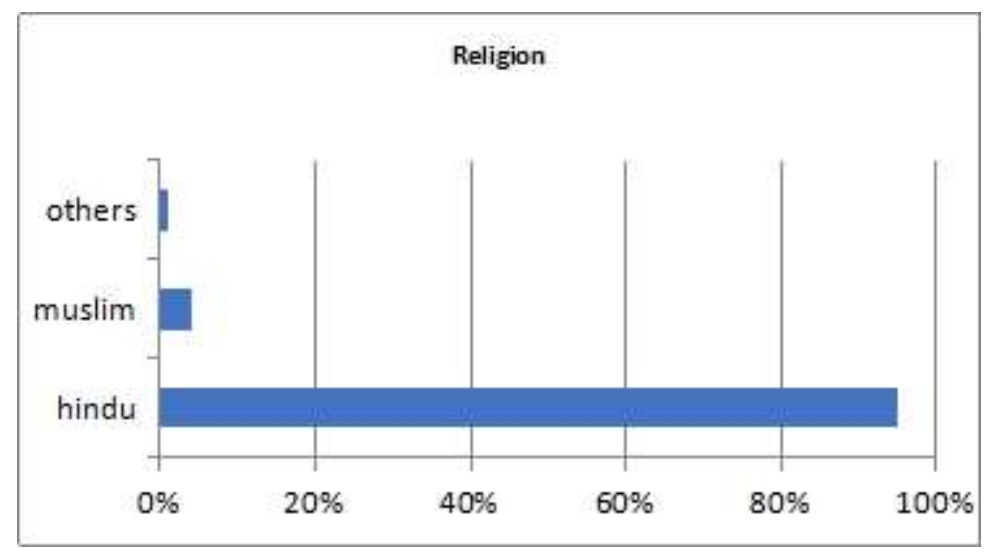

Fig.No.5: Cone diagram shows the percentage-wise distribution of religion.

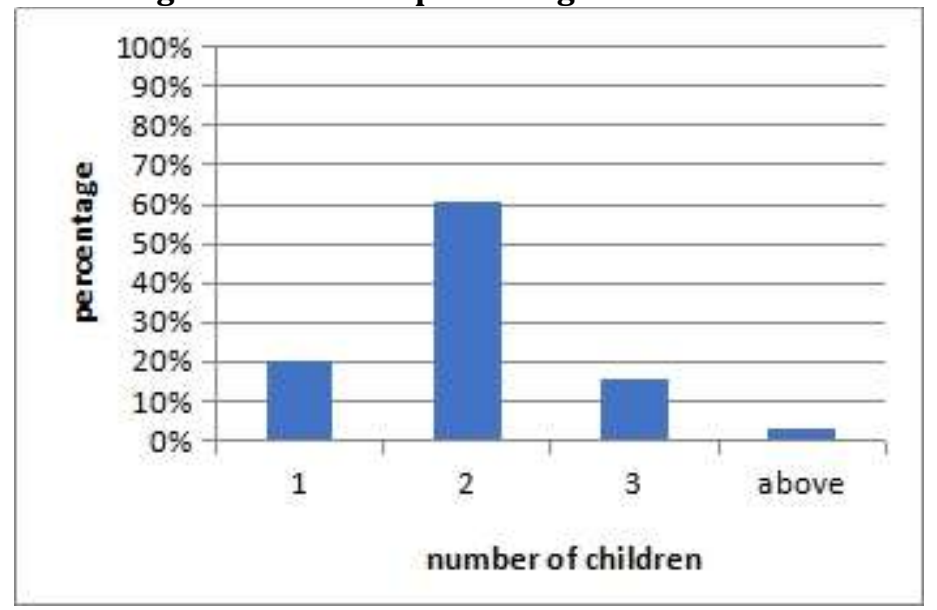

Fig.No.6: pyramid Diagram shows the percentage-wise distribution of the number of children 
EPRA International Journal of Multidisciplinary Research (IJMR) - Peer Reviewed Journal

Volume: 6 | Issue: 6 | June 2020 || Journal DOI: 10.36713/epra2013 || SJIF Impact Factor: 7.032 ||ISI Value: 1.188

Assess the knowledge of parents on impact of television viewing on children in selected community area Kanpur.

\begin{tabular}{|c|c|c|}
\hline Percentage-wise knowledge Score & Frequency & Percentage \\
\hline Poor knowledge- $(1-5)$ & 8 & $8 \%$ \\
\hline Average knowledge- $(6-10)$ & 36 & $36 \%$ \\
\hline Good knowledge- $(11-15)$ & 50 & $50 \%$ \\
\hline Very good knowledge- $(16-20)$ & 06 & $6 \%$ \\
\hline
\end{tabular}

Table No.1: Showing percentagewise knowledge score of parents

Attitude score of parents on impact of television viewing on children in selected community area, Kanpur.

\begin{tabular}{|c|c|c|}
\hline Level of attitude & Frequency & Percentage \\
\hline Positive attitude & 84 & $84 \%$ \\
\hline Negative attitude & 16 & $16 \%$ \\
\hline
\end{tabular}

Table No.2: Showing percentagewise Attitude score of parents

\begin{tabular}{|c|c|c|}
\hline & Mean & SD \\
\hline Knowledge & 10.7 & 3.5 \\
\hline Attitude & 48.81 & 5.54 \\
\hline
\end{tabular}

Table No. 3: The mean and standard deviation for knowledge and attitude.

Co-relation between the knowledge and attitude score of parents regarding the impact of television on children in selected area in community, Kanpur.

\begin{tabular}{lccl}
\hline CATEGORY & CORRELATION & DF & INFERENCE \\
\hline Knowledge and attitude & 0.605 & 98 & positive
\end{tabular}

Table No:4 Correlation b/w knowledge and attitude

To find out the association between the level of knowledge score with selected demographic variables.

\begin{tabular}{|c|c|c|c|c|c|c|c|c|}
\hline $\begin{array}{l}\text { Demograph } \\
\text { ic variables }\end{array}$ & Categories & Poor & $\begin{array}{l}\text { Averag } \\
\text { e }\end{array}$ & Good & $\begin{array}{l}\text { Very } \\
\text { Goo } \\
\text { d }\end{array}$ & $\mathrm{X}^{2}$ & Df & Interference \\
\hline $\begin{array}{l}\text { 1.Age of } \\
\text { Parents: }\end{array}$ & $\begin{array}{l}\text { (a) 21-27year } \\
\text { (b) 28-34year } \\
\text { (c) 35-42year }\end{array}$ & $\begin{array}{l}0 \\
1 \\
1 \\
\end{array}$ & $\begin{array}{l}7 \\
27 \\
17 \\
\end{array}$ & $\begin{array}{l}7 \\
22 \\
11 \\
\end{array}$ & $\begin{array}{l}1 \\
4 \\
2\end{array}$ & 9.31 & 6 & $\begin{array}{l}\text { T-12.59 } \\
\text { Non-significant }\end{array}$ \\
\hline $\begin{array}{l}\text { 2.Types of } \\
\text { Family: }\end{array}$ & $\begin{array}{l}\text { (a) Nuclear } \\
\text { (b) Joint } \\
\text { (c) Extended }\end{array}$ & $\begin{array}{l}1 \\
1 \\
0\end{array}$ & $\begin{array}{l}16 \\
32 \\
3\end{array}$ & $\begin{array}{l}6 \\
32 \\
0\end{array}$ & $\begin{array}{l}1 \\
6 \\
0\end{array}$ & 8.01 & 6 & $\begin{array}{l}\text { T- } 12.59 \\
\text { Non-significant }\end{array}$ \\
\hline $\begin{array}{l}\text { 3.Educationa } \\
\text { l status of } \\
\text { Parents: }\end{array}$ & $\begin{array}{l}\text { (a) Up to } 8^{\text {th }} \text { standard } \\
\text { (b)High school } \\
\text { (c)Inter-mediate } \\
\text { (d)Graduation }\end{array}$ & $\begin{array}{l}1 \\
1 \\
0 \\
0\end{array}$ & $\begin{array}{l}16 \\
23 \\
6 \\
6 \\
\end{array}$ & $\begin{array}{l}7 \\
16 \\
3 \\
14\end{array}$ & $\begin{array}{l}1 \\
2 \\
2 \\
2\end{array}$ & $\begin{array}{l}11.6 \\
9\end{array}$ & 9 & $\begin{array}{l}\text { T- } 16.92 \\
\text { Non-significant }\end{array}$ \\
\hline
\end{tabular}




\begin{tabular}{|c|c|c|c|c|c|c|c|c|}
\hline $\begin{array}{l}\text { 4. Income of } \\
\text { Parents }\end{array}$ & $\begin{array}{l}\text { (a) < 10000 Rs. /month } \\
\text { (b) } 10001-2000 \text { Rs. } \\
\text { /month } \\
\text { (c) } 20001-30000 \text { Rs. } \\
\text { /month } \\
\text { (d) }>30000 \text { Rs. /month }\end{array}$ & $\begin{array}{l}2 \\
0 \\
0 \\
0\end{array}$ & $\begin{array}{l}27 \\
17 \\
7 \\
0\end{array}$ & $\begin{array}{l}18 \\
15 \\
4 \\
3\end{array}$ & $\begin{array}{l}2 \\
3 \\
1 \\
1\end{array}$ & 8.5 & 9 & $\begin{array}{l}\mathrm{T}-16.93 \\
\text { Non-significant }\end{array}$ \\
\hline 5. Religion & $\begin{array}{l}\text { (a) Hindu } \\
\text { (b) Muslim } \\
\text { (c) others }\end{array}$ & $\begin{array}{l}2 \\
0 \\
0\end{array}$ & $\begin{array}{l}47 \\
3 \\
1\end{array}$ & $\begin{array}{l}39 \\
1 \\
0\end{array}$ & $\begin{array}{l}7 \\
0 \\
0\end{array}$ & 2.07 & 6 & $\begin{array}{l}\text { T- } 12.59 \\
\text { non-significant }\end{array}$ \\
\hline $\begin{array}{l}\text { 6. Number } \\
\text { Of children }\end{array}$ & $\begin{array}{l}\text { (a) } 1 \\
\text { (b) } 2 \\
\text { (c) } 3 \\
\text { (d) above }\end{array}$ & $\begin{array}{l}0 \\
1 \\
0 \\
1\end{array}$ & $\begin{array}{l}10 \\
31 \\
9 \\
1\end{array}$ & $\begin{array}{l}8 \\
25 \\
6 \\
1\end{array}$ & $\begin{array}{l}2 \\
4 \\
1 \\
0\end{array}$ & $\begin{array}{l}16.5 \\
9\end{array}$ & 9 & $\begin{array}{l}\text { T-16.92 } \\
\text { non-significant }\end{array}$ \\
\hline
\end{tabular}

Table:5 Association between demographic variables with their attitude score

To find out the association between the level of attitude score with selected demographic variables.

\begin{tabular}{|c|c|c|c|c|c|c|}
\hline $\begin{array}{l}\text { Demographic } \\
\text { variables }\end{array}$ & Categories & $\begin{array}{l}\text { Positive } \\
\text { Attitude }\end{array}$ & $\begin{array}{l}\text { Negative } \\
\text { Attitude }\end{array}$ & $\mathrm{X}^{2}$ & Df & Inference \\
\hline 1.Age of Parents: & $\begin{array}{l}\text { (a) 21-27year } \\
\text { (b) 28-34year } \\
\text { (c) 35-42year }\end{array}$ & $\begin{array}{l}2 \\
7 \\
8\end{array}$ & $\begin{array}{l}13 \\
47 \\
23\end{array}$ & 2.43 & 2 & $\begin{array}{c}\text { T- } 5.99 \\
\text { non- } \\
\text { significant }\end{array}$ \\
\hline $\begin{array}{l}\text { 2.Types of } \\
\text { Family: }\end{array}$ & $\begin{array}{l}\text { (a) Nuclear } \\
\text { (b) Joint } \\
\text { (c) Extended }\end{array}$ & $\begin{array}{c}4 \\
13 \\
0\end{array}$ & $\begin{array}{c}20 \\
60 \\
3\end{array}$ & 11.18 & 2 & $\begin{array}{c}\mathrm{T}-5.99 \\
\text { significant }\end{array}$ \\
\hline $\begin{array}{l}\text { 3.Educational } \\
\text { status of } \\
\text { Parents: }\end{array}$ & $\begin{array}{l}\text { (a) Up to } 8^{\text {th }} \\
\text { standard } \\
\text { (b)High school } \\
\text { (c)Inter-mediate } \\
\text { (d)Graduation }\end{array}$ & $\begin{array}{l}6 \\
8 \\
2 \\
1\end{array}$ & $\begin{array}{c}19 \\
34 \\
9 \\
21\end{array}$ & 14.27 & 3 & $\begin{array}{c}\text { T-7.82 } \\
\text { significant }\end{array}$ \\
\hline $\begin{array}{l}\text { 4. Income of } \\
\text { Parents }\end{array}$ & $\begin{array}{l}\text { (a) }<10000 \text { Rs. } \\
/ \text { month } \\
\text { (b) } 10001-20000 \\
\text { Rs. /month } \\
\text { (c) } 20001-30000 \\
\text { Rs. /month } \\
\text { (d) }>30000 \text { Rs. } \\
/ \text { month }\end{array}$ & $\begin{array}{c}10 \\
4 \\
2 \\
1\end{array}$ & $\begin{array}{c}39 \\
31 \\
10 \\
3\end{array}$ & 10.77 & 3 & $\begin{array}{c}\text { T- } 7.82 \\
\text { Significant }\end{array}$ \\
\hline 5. Religion & $\begin{array}{l}\text { (a) Hindu } \\
\text { (b) Muslim } \\
\text { (c) others }\end{array}$ & $\begin{array}{c}15 \\
2 \\
0\end{array}$ & $\begin{array}{c}80 \\
2 \\
1\end{array}$ & 3.37 & 2 & $\begin{array}{c}\text { T- } 5.99 \\
\text { non- } \\
\text { significant }\end{array}$ \\
\hline
\end{tabular}




\begin{tabular}{|l|c|c|c|c|c|c|}
\hline 6. Number Of & (a) 1 & 10 & 51 & & & \\
children & (b) 2 & 5 & 11 & 4.89 & 3 & T-7.82 \\
& (c) 3 & 1 & 2 & & & Significant \\
\hline
\end{tabular}

Table:6 Association between demographic variables with their attitude score

\section{DISCUSSION}

In this study it was found that

Fig.no-1: Majority $54 \%$ of parents were between age group of 28-34 years and lowest $15 \%$ were $21-27$ years.

Fig.no:2 Percentage distribution as per types of family shows that the highest percentage $73 \%$ family were joint and 24\% family were nuclear and 3\%family were extended.

Fig.no:3 Percentage distribution to their educational status shows that the highest percentage $(42 \%)$ of parents had high school education $25 \%$ parents had up to 8 class education and $22 \%$ parents had graduation $11 \%$ parents had intermediate education.

Fig.no:4 Percentage distribution according to their income 49\%parents had income less than $10000 \mathrm{rs} /$ month and 35\%parents had income 10001$20000 \mathrm{rs} /$ month $12 \%$ parents had 20001-30000rs/month and $4 \%$ parents had income $30000 \mathrm{rs} /$ month.

Fig.no:5 Percentage distribution of religion of parents $95 \%$ of parents had Hindu 4\%parents had Muslim and $1 \%$ parents had others religion.

Fig.no:6 Percentage distribution of no of child $61 \%$ parents had 2 children 20\%parents had 1 child $16 \%$ parents had 3 children and $3 \%$ of children had above 3 children.

Table-1: is showing Percentage distribution of level of knowledge $50 \%$ parents had good knowledge $36 \%$ of parents had average knowledge $8 \%$ parents had poor knowledge $6 \%$ parents had very good knowledge.

Table-2: is presenting Percentage distribution of level of attitude $84 \%$ of parents had a positive attitude and 16 $\%$ parents had a negative attitude.

Table-4: shows positive correlation between knowledge and attitude at the level of 0.05 .

Table-5: Shows that there was no significant association between knowledge score and selected demographic variables like age of parents, types of family, educational status of the parents, an income of parents, religion, and number of children.

Table-6: Shows that there was no significant association between attitude score and selected demographic variables like age of parents, religion, except, type of family, educational status of the parents, an income of the parents, and the number of children.

\section{REFERENCES}

1. IJolin em weller ra "television viewing and its impact on children behaviors, $A$ guide to information and support for parents, 2010 page no 16 25 (www.iosrjouranals.org.)

2. ${ }^{2}$ Pearson et.al child hood obesity, international journal of behavioral nutrition and physical activity ,2011, page no 16-25 (httpsyediatrics;appoblications;com.)

3. ${ }^{3}$ Television; reducing the negative impact available from URL, http/www.med.umich.eda//llibt/pa/pa televised the.htm.2005 